\title{
PLIOCENE BRACHIOPODS FROM THE ESTEPONA AREA (MÁLAGA, SOUTH SPAIN)
}

\author{
Maria Aleksandra BITNER' and Jordi MARTINELL ${ }^{2}$ \\ 'Instytut Paleobiologii PAN, ul. Twarda 51/55, PL-00-818 Warszawa, Poland. E-mail: \\ bitner@twarda.pan.pl \\ 2 Departament d’Estratigrafia Paleontologia i Geociències Marines, Facultat de Geologia, \\ Universitat de Barcelona. C/ Martí i Franquès s/n. E-08028-Barcelona, Spain. E-mail: \\ jordim@natura.geo.ub.es
}

Bitner, M.A. and Martinell, J. 2001. Pliocene brachiopods from the Estepona area (Málaga, South Spain). [Braquiópodos pliocenos del área de Estepona (Málaga, sur de España).] Revista Española de Paleontología, 16(2), 177-185. ISSN 0213-6937.

\begin{abstract}
Four brachiopod species (one rhynchonellid and 3 terebratulids) from Lower Pliocene sandy deposits of the Estepona area in the Málaga province (Andalusia, southern Spain) are described: Aphelesia bipartita (Brocchi), Terebratula terebratula (Linnaeus), Gryphus sp., and Megerlia eusticta (Philippi). M. eusticta is restricted to the Pliocene, but $A$. bipartita and $T$. terebratula are also regarded as characteristic Pliocene species, although they are reported from the Miocene as well. The investigated assemblage differs from all other Spanish Pliocene assemblages mostly in the absence of such genera as Megathyris, Argyrotheca and Terebratulina. The assemblages of similar composition to that from the Estepona area are associated with shallow water, highenergy environments and sandy facies through the whole Mediterranean region.
\end{abstract}

Keywords: Brachiopoda, Zanclean, Lower Pliocene, systematics, Málaga, Andalusia, South Spain, western Mediterranean.

\section{RESUMEN}

Se describen cuatro especies de braquiópodos (un rinconélido y 3 terebratúlidos) identificados en los depósitos de arenas del Plioceno Inferior del área de Estepona (Málaga, Andalucía): Aphelesia bipartita (Brocchi), Terebratula terebratula (Linnaeus), Gryphus sp. y Megerlia eusticta (Philippi). M. eusticta tiene una distribución restringida al Plioceno; A. bipartita y T. terebratula, aunque son especies características del Plioceno, se conocen también del Mioceno. La asociación estudiada difiere de las restantes conocidas del Plioceno español, especialmente por la ausencia de géneros tales como Megathyris, Argyrotheca y Terebratulina. Asociaciones de composición similar a la del área de Estepona están asociadas a ambientes de alta energía en aguas poco profundas y de facies arenosas en toda la región mediterránea.

Palabras clave: Brachiopoda, Zancleense, Plioceno Inferior, sistemática, Málaga, Andalucía, España, Mediterráneo occidental.

\section{INTRODUCTION}

Pliocene brachiopods of Spain have been mentioned or listed by a number of authors in studies of molluscan faunas (see Faura and Sans, 1916; Brébion et al., 1971, 1978; González Donoso and Porta, 1977; Martinell and Villalta, 1977), but more detailed studies are rare. Pajaud (1976, 1977) recognized 2 and 8 species in the brachiopod assemblages from the regions of Alicante and Almería, south-eastern Spain, respectively. From the Empordà basin, Catalonia, north-eastern Spain, an assemblage of 5 brachiopod species was described by Encinas (1992; see also Encinas and Martinell, 1992). Recently the first occurrence of Megerlia eusticta (Philippi) in the Pliocene of Spain was reported by Calzada (1997) from the Almería region.

Brachiopods in Pliocene strata are also recorded from other Mediterranean countries. Being common and diversified, they have been the subject of intensive paleontological and paleoecological studies in recent years (e.g., Elliott, 1960; Dermitzakis, 1969; Tavani, 1969; Anfossi et al., 1983; Gaetani and Saccà, 1984, 


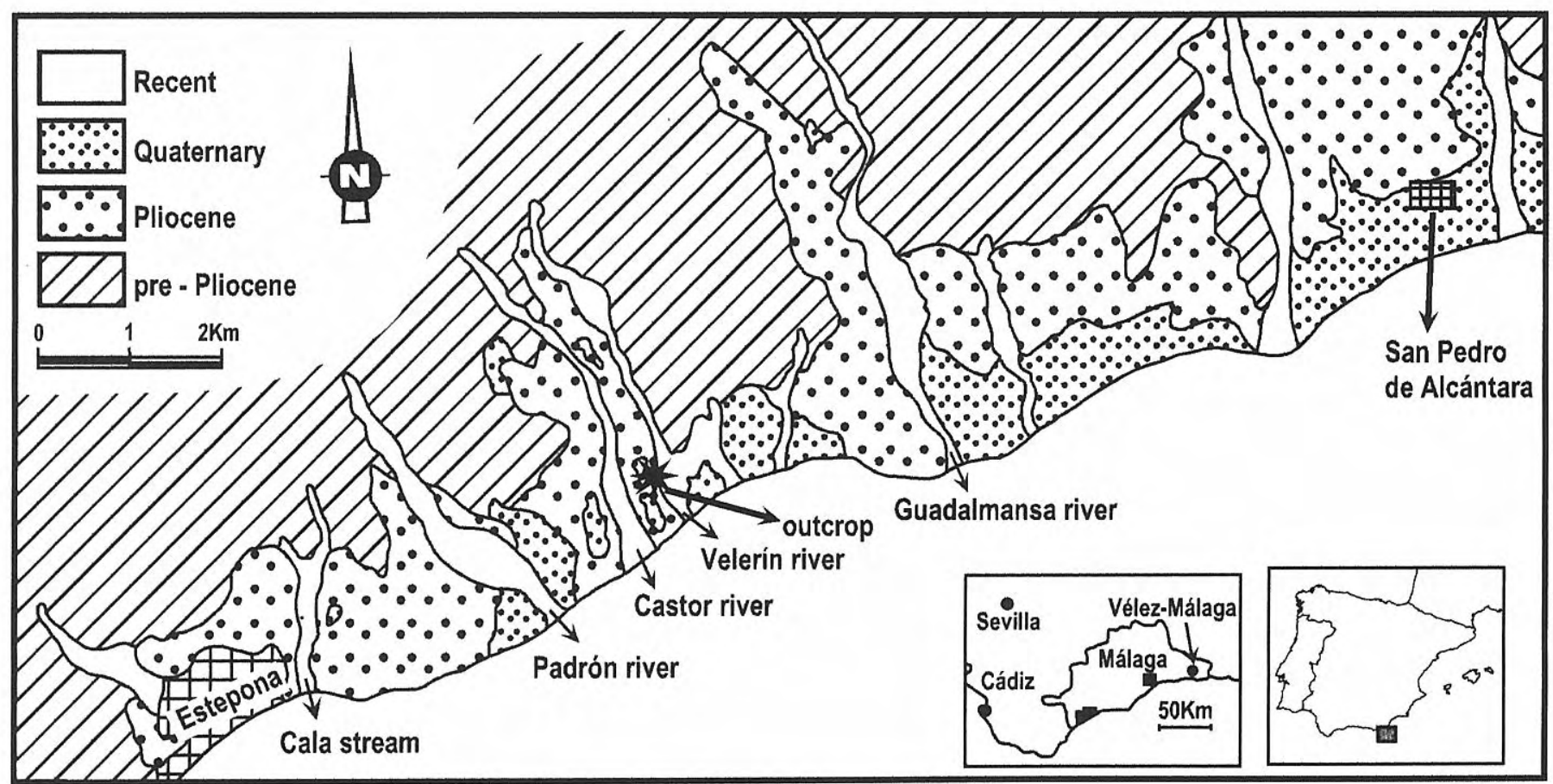

Figure 1. Geographical and geological location of the studied outcrop.

1985a, b; Georgiades-Dikeoulia, 1984; Gaetani, 1986; Saccà, 1986; Barrier et al., 1987; Spano, 1989; Benigni and Robba, 1990; Taddei Ruggiero, 1994, 1996).

This paper presents the first description of the Pliocene brachiopod assemblage outcrops in the Velerín region, located in the Estepona area (Málaga, Andalusia, southern Spain). Until recently, the only record of brachiopods from this area was that of González Donoso and Porta (1977) who gave a list of four species: Terebratula sp., Griphus sp. [sic], Megathiris sp., and Megerlia truncata (Linnaeus). The investigated assemblage is also composed of four species, but a slight difference in composition is observed. The genus Megathiris is absent, while Megerlia is represented by another species, $M$. eusticta, and an additional element is Aphelesia bipartita (Brocchi). González Donoso and Porta (1977) presented neither illustrations nor descriptions, and it is difficult to estimate the accuracy of their determinations. Thus, it is possible that this is the same assemblage as described here despite apparent differences in taxonomic composition.

All specimens described herein are housed in the Institute of Paleobiology of the Polish Academy of Sciences (Warszawa) under the collection number ZPAL Bp.XLIV.

\section{GEOGRAPHICAL AND GEOLOGICAL SETTINGS}

There are two major marine Pliocene areas in the Málaga coastal region: the larger one, situated between Estepona and San Pedro de Alcántara towns, and a smaller one to the west near Vélez-Málaga, respectively (Fig. 1). The Pliocene deposits of the region outcrop along a band of variable width along the coast and lie discordantly over the Alpujárride, Maláguide and El Campo de Gibraltar Complexes, or over transgressive Neogene formations of the Grupo de la Viñuela (Chamón et al., 1978; Sanz de Galdeano et al., 1993).

The Pliocene sediments constitute a transgressive sequence in the Estepona-San Pedro de Alcántara area, in which two groups may be recognized. The lower one is represented by canalized conglomerates interbedded with intermittent layers of sands, and an upper one is represented by sands (Muñíz-Solís and Guerra-Merchán, 1994) (Fig. 2). The brachiopod fauna studied comes from the Velerín outcrop, in the Estepona area (Figs. 1,2) and occurs in sandy sediments.

Despite the interest aroused by the study of the Málaga Pliocene beds, few studies have been carried out until recently. See Vera-Peláez (1996) and LozanoFrancisco (1997) for further information.

The age of the greater part of the Malacitan marine Pliocene has been established as Zanclean on the basis of the study of foraminiferans, calcareous nannoplakton, ostracods and molluscs (González Donoso and Porta, 1977; Aranki, 1987; Aguirre, 1995; Vera-Peláez, 1996; Lozano-Francisco, 1997).

\section{SOME TAPHONOMICAL CONSIDERATIONS}

The Velerín outcrop (Fig. 1), which is up to $30 \mathrm{~m}$ thick, is located near the border of the Pliocene basin and coarse detritic facies prevail in it (lower group of MuñízSolís and Guerra-Merchán, 1994). Velerín is characterized by the conglomeratic facies with canalized bottoms and imbricated pebbles at the base (Fig. 2). 
Locally, massive sands, sands with pebbles or crossbedded sands are intercalated.

This outcrop is especially rich in molluscan fossils, some of them with traces of their original coloration. Nevertheless, the skeletal remains of the site have mostly undergone some transport and reworking prior to burial, as is evident in other parts of the basin. As a result, molluscan fossils usually show poor preservation (disarticulation, abrasion, some breaking, etc.). However the brachiopods at Velerín are excellently preserved, all articulated with no breakage, and were not transported or reworked.

Overall, the preliminary taphonomical studies of the outcrops revealed different degrees of faunal reworking, although without significant displacement. Only one of them (Parque Antena outcrop) has been studied in detail from a taphonomical point of view (Guerra-Merchán et al., 1996). Fossils at this site perhaps show the best preservation in the whole basin, with very little transport of the skeletal remains.

\section{SYSTEMATIC DESCRIPTION}

\author{
PHYLUM BRACHIOPODA Duméril, 1806 \\ SUBPHYLUM RHYNCHONELLIFORMEA Williams \\ et al., 1996 \\ CLASS RHYNCHONELLATA Williams et al., 1996 \\ ORDER RHYNCHONELLIDA Kuhn, 1949 \\ Superfamily RHYNCHONELLOIDEA d'Orbigny,
} 1847

Nomenclatural note: As recently indicated by Manceñido et al. (1993), the family-group names based on the genus Rhynchonella should be attributed to d'Orbigny, not Gray.

Family Basiliolidae Cooper, 1959

Subfamily Aphelesiinae Cooper, 1959

Genus Aphelesia Cooper, 1959

Type species: Anomia bipartita Brocchi, 1814.

\section{Aphelesia bipartita (Brocchi, 1814)} Figs. 3A-H

1814 Anomia bipartita Brocchi, 469, pl. 10, fig. 7.

1959 Aphelesia bipartita (Brocchi); Cooper, 41-42, pl. 7, figs. 12-22; pl. 8, figs. 13-18; pl. 22, figs. 18-25.

1985a Aphelesia bipartita (Brocchi); Gaetani and Saccà, 5, text-fig. 2, pl. 7, figs. 1-4.

1985b Aphelesia bipartita (Brocchi); Gaetani and Saccà, 363-365, text-figs. 2-3, pl. 17, figs. 1-3; pl. 19, figs. 1-3.

Dimensions (in $\mathrm{mm}$ ):

Width

Thickness

ZPAL Bp.XLIV/2

20.0

19.3

11.0

19.2

21.1

11.8

19.6

22.6

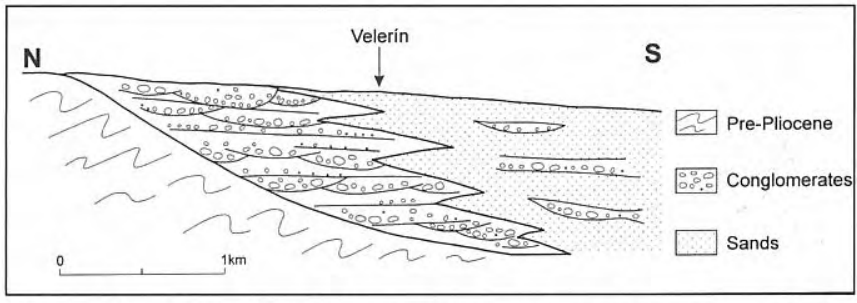

Figure 2. Simplified diagram of the stratigraphy of the Pliocene of the Estepona area with indication of the situation of Velerín outcrop.

Material: Eight complete specimens.

\section{Remarks}

The investigated specimens resemble very closely those described and illustrated by Cooper (1959) and Gaetani and Saccà (1985a, b). The shell is subtriangular to subpentagonal in outline and dorsibiconvex. The anterior commissure is uniplicate with a broad fold on the dorsal valve. The shell surface is smooth with very incipient costation on the anterior margin and numerous growth lines. The foramen is small, hypothyrid with conjunct deltidial plates. The pedicle collar is sessile. The internal features observed in one slightly damaged specimen show characters typical of the genus. The teeth are supported by well-developed dental plates. Outer and inner hinge plates are absent, as is also the cardinal process. There is a low median ridge on the dorsal valve. The crura are broken.

This species is common and well known in the Late Tertiary in the Mediterranean region, but has not previously been described from Spain, apart from a record from the Pliocene strata of the Elche region (Brébion et al., 1971). Pajaud (1976, 1977) described a new rhynchonellid genus and species, Phapsirhynchia sanctapaulensis, from the Lower Pliocene of the Alicante and Almería regions in southern Spain. However, according to Llompart and Calzada (1982) and Gaetani and Saccà (1985b) there is no reason to erect this new genus, and Pajaud's species should be assigned to the genus Aphelesia. The species A. sanctapaulensis (Pajaud, 1976) differs from the investigated specimens in having more distinct ribs on the anterior margin, and narrow, high uniplication (see pl. 3, fig. E in Pajaud 1976).

Aphelesia bipartita was also reported from the Miocene of Hungary by Meznerics (1943). She described as well a new species Hemithiris acuta, which is very similar to A. bipartita. Examination of the collection kept in the Hungarian Museum of Natural History by one of the authors did not allow deciding of validity of those determinations. The material of $A$. bipartita is very badly preserved, and the specimens are smaller and more elongate than typical $A$. bipartita. In turn, the specimens described as $H$. acuta display a great similarity to $A$. bipartita, and probably this species may be synonymous with A. bipartita.

The specimens under study differ from $A$. pseudobipartita (Sacco, 1902), the species known from the Pliocene of Italy, in being much larger and having 


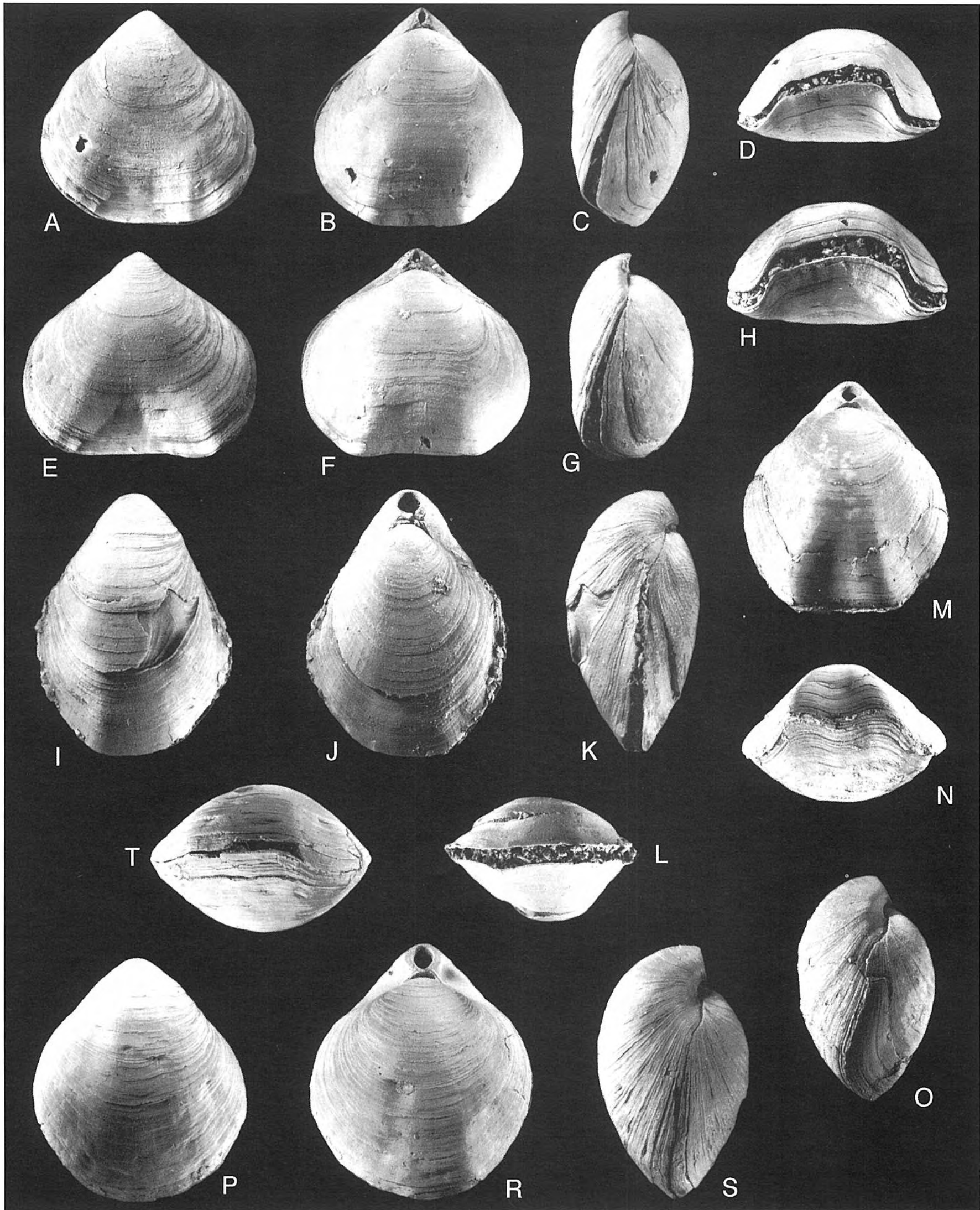

Figure 3. A-H. Aphelesia bipartita (Brocchi), complete specimens, ZPAL Bp.XLIV/1-2, x 2; A, E - ventral views; B, F dorsal views; C, G - lateral views; D, H - anterior views. I-L. Gryphus sp., complete specimen, ZPAL Bp.XLIV/13, x 2; I - ventral view, J - dorsal view, K - lateral view; L - anterior view. M-T. Terebratula terebratula (Linnaeus), complete specimens, ZPAL Bp.XLIV/9-10, x 1; M, R - dorsal views; N, T - anterior views; O, S lateral views; P ventral view. All specimens from Velerín. 
much less distinct ribs on the margin (Gaetani and Saccà, 1985b).

\section{Occurrence}

Aphelesia bipartita is reported from the Miocene of Hungary (Meznerics, 1943) and Malta (Pedley, 1976), and from the Pliocene of Spain (Brébion et al., 1971) and Italy (Gaetani and Saccà, 1985a, b).

ORDER TEREBRATULIDA Waagen, 1883 SUBORDER TEREBRATULIDINA Waagen, 1883 Superfamily TEREBRATULOIDEA Gray, 1840 Family Terebratulidae Gray, 1840 Subfamily Terebratulinae Gray, 1840 Genus Terebratula Müller, 1776

Type species: Anomia terebratula Linnaeus, 1758.

\section{Terebratula terebratula (Linnaeus, 1758) Figs. 3M-T}

1976 Terebratula terebratula (Linnaeus); Pajaud, 100-102, text-fig. 1, pl. 3, figs. A-C.

1977 Terebratula terebratula (Linnaeus); Pajaud, 6, pl 2, figs. C-E.

1982 Terebratula terebratula (Linnaeus); Llompart and Calzada, 190-192, pl. 1, figs. 1-2.

1992 Terebratula terebratula (Linnaeus); Encinas, 88-94, pl. 6, figs. A-F; pl. 9, figs. A-B; pl. 10, fig. A.

1992 Terebratula terebratula (Linnaeus); Encinas and Martinell, 504.

Dimensions (in mm; figured specimens):

$\begin{array}{lccc} & \text { L } & \text { W } & \text { T } \\ \text { ZPAL Bp.XLIV/9 } & 42.2 & 36.3 & 25.4 \\ \text { ZPAL Bp.XLIV/10 } & 45.6 & 39.1 & 27.4\end{array}$

Material: Four complete specimens.

\section{Remarks}

The investigated specimens correspond very well to those described from the Pliocene deposits of Spain by Pajaud (1976, 1977) and Encinas (1992). They differ, however, from Pajaud's specimens in being smaller. Terebratula terebratula is a large species, with smooth surface and nearly equally biconvex shell. The lateral commissure varies from nearly straight to gently curved toward ventral side, while anterior commissure can be slightly uniplicate to sulciplicate. The beak is short, suberect to erect with a large, circular foramen of permesothyrid type. The symphytium is partly visible.

The nomenclatural problem of the so-called large Terebratula species has been pointed out by several authors (compare Calzada, 1978; Llompart and Calzada, 1982; Gaetani and Saccà 1985a). Gaetani and Saccà (1985a) in their revision distinguished three Terebratula species: T. sinuosa (Brocchi, 1814) from the Miocene, $T$. calabra Seguenza, 1871 from the Pliocene, and T. scillae Seguenza, 1871 from the Pleistocene. They placed the specimens from the Pliocene of Spain described by Pajaud $(1976,1977)$ into the synonymy of $T$. calabra. Gaetani and Saccà (1985a) indicated that some specimens from Italy described as T. terebratula are probably synonymous with $T$. scillae as the deposits from where those specimens come are of the Pleistocene age. Because the type species of the genus Terebratula was not officially recognized (see Buckman, 1907), the priority of the name terebratula was not valid in their opinion.

Since the lack of the formally designated type species of the genus Terebratula provoked a lot of problems, Lee and Brunton (1998) undertook an attempt to resolve this confusion. They collected new material from the rediscovered type locality, a calcarenite of Pliocene age, and selected a specimen as neotype for T. terebratula. Following it, Anomia terebratula Linnaeus, 1758 was officially accepted as the type species of the genus Terebratula (Opinion 1959 of the International Commission on Zoological Nomenclature in the Bulletin of Zoological Nomenclature, $57^{\circ}$ (3), September 2000).

The re-evaluation of the late Cenozoic species assigned to the genus Terebratula has been also announced (Lee and Brunton, 2000; D.E. Lee, personal communication). All Terebratula species show a great similarity and it is doubtful if the age only can decide about the species attribution as proposed by Gaetani and Saccà (1985a).

\section{Occurrence}

Terebratula terebratula is reported from the Miocene of Malta (Pedley, 1976) and Spain (Llompart and Calzada, 1982), and from the Pliocene of Spain (Pajaud, 1976, 1977; Encinas, 1992). Large Terebratula species from the Tertiary of other Mediterranean regions (Dermitzakis, 1969; Georgiades-Dikeoulia, 1984; Gaetani and Saccà, 1985a; Taddei Ruggiero, 1994, 1996) are also noted under different specific names (see discussion above).

Subfamily Gryphinae Sahni, 1929

Genus Gryphus Megerle von Mühlfeld, 1811

Type species: Anomia vitrea Born, 1778.

Gryphus sp.

Fig. 3I-L

Material: One complete specimen, measuring $24.2 \mathrm{~mm}$ long, $18.5 \mathrm{~mm}$ wide, and $12.7 \mathrm{~mm}$ thick.

\section{Description}

The medium-sized shell is oval, biconvex with the ventral valve more convex than the dorsal one. The shell surface is smooth, ornamented only by numerous growth lines. The lateral commissure is straight, and the anterior commissure is rectimarginate. The short, suberect beak is truncated by a large, circular foramen of epithyrid type. The symphytium is only slightly visible. The internal features are unknown. 


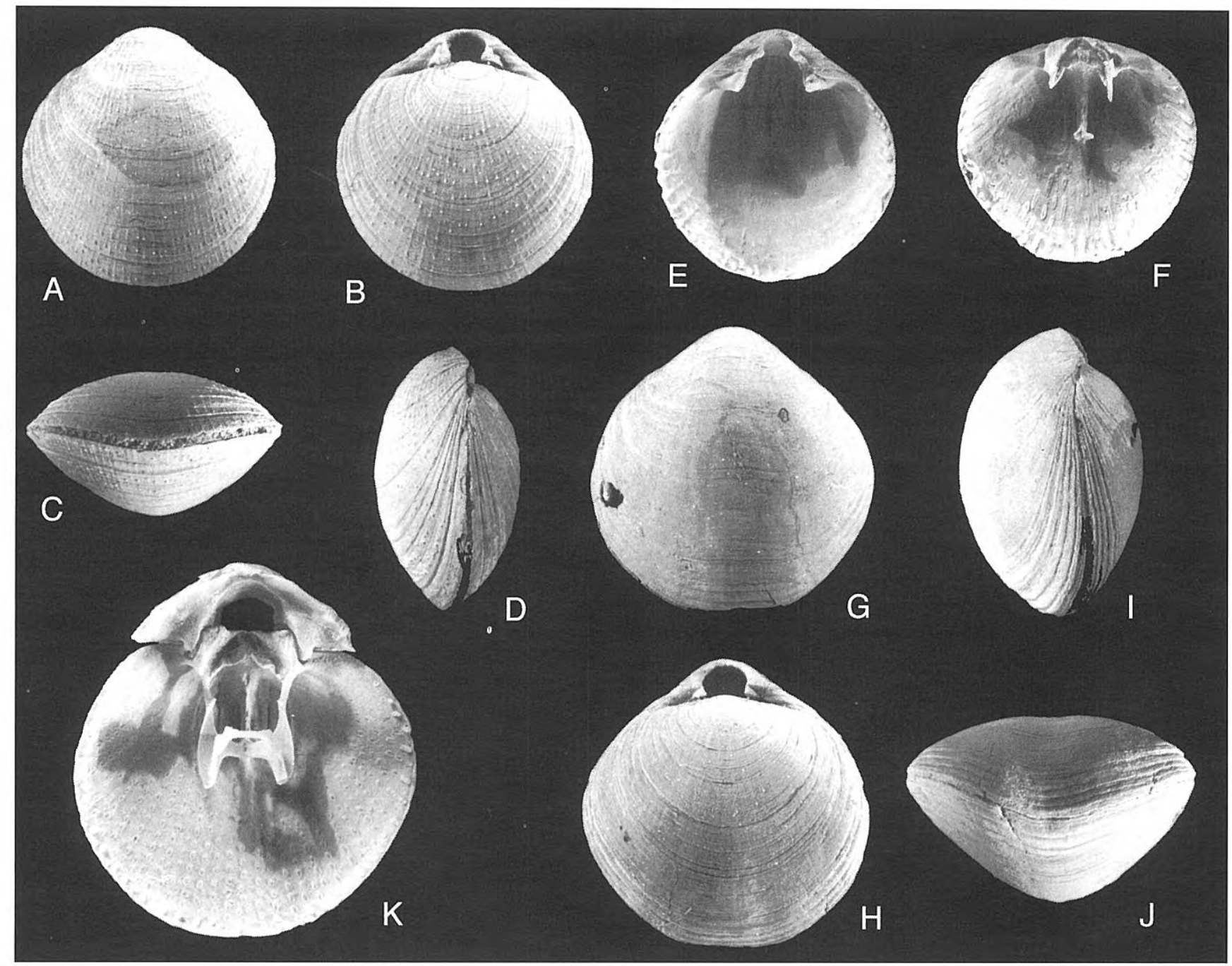

Figure 4. Megerlia eusticta (Philippi),Velerín; A-D. Complete specimen, ZPAL Bp.XLIV/14, x 3; A - ventral view; B dorsal view; C - anterior view; D - lateral view. E-F. Inner views, ZPAL Bp.XLIV/16, x 3; E - ventral valve; F dorsal valve. G-J. Complete specimen, ZPAL Bp.XLIV/15, x 3; G - ventral view; H - dorsal view; I - lateral view; J - anterior view. K. Inner view of dorsal valve, ventral valve partially destroyed to show brachidium, ZPAL Bp.XLIV/17, x 4.5 .

\section{Remarks}

The limited material prevents detailed investigations and identification to the specific level, however, in external characters the investigated specimen agrees very well with the diagnosis of the genus (Cooper, 1983). The presence of this genus was already noted by González Donoso and Porta (1977: 53), listed with incorrect spelling, Griphus sp.

In size, shell outline, type of foramen the studied specimen resembles the Pliocene species Gryphus sphenoideus (Philippi, 1844) as described and illustrated by Gaetani and Saccà $(1984,1985 a)$. It differs from $G$. minor (Philippi, 1836), another Pliocene species from Italy, in being much larger (see Gaetani and Saccà, 1985a).

\section{Occurrence}

The genus Gryphus is recorded from the Pliocene and Pleistocene deposits of Italy (Gaetani and Saccà, 1984, 1985a) and lives at present in the Mediterranean Sea (Logan, 1979; Emig, 1989a, b) and the Atlantic Ocean at depths from 70 to 2663 m (e.g., Brunton and Curry, 1979; Cooper, 1981, 1983).

SUBORDER TEREBRATELLIDINA Muir-Wood, 1955

Superfamily KRAUSSINOIDEA Dall, 1870

Family Kraussinidae Dall, 1870

Genus Megerlia King, 1850

Type species: Anomia truncata Linnaeus, 1767.

\section{Megerlia eusticta (Philippi, 1836)}

Fig. 4A-K

1836 Terebratula eusticta Philippi, 98, pl. 6, fig. 9.

1985a Megerlia eusticta (Philippi); Gaetani and Saccà, 16-

17 , text-fig. 11, pl. 10, figs. 1-9; pl. 11, figs. 6-12.

1997 Megerlia eusticta (Philippi); Calzada, 31-32, figs. 1-3. 
Dimensions (in mm):

$\begin{array}{lccc} & \text { L } & \text { W } & \text { T } \\ \text { ZPAL Bp.XLIV/14 } & 12.4 & 11.9 & 6.8 \\ \text { ZPAL Bp.XLIV/15 } & 13.8 & 13.4 & 8.9 \\ \text { ZPAK Bp.XLIV/18 } & 13.1 & 12.8 & 7.9 \\ \text { ZPAL Bp.XLIV/19 } & 13.7 & 13.8 & 7.7\end{array}$

Material: 14 complete specimens.

\section{Remarks}

Megerlia eusticta, reported for the second time from Spain, is a very characteristic and easily recognisable species which displays a small, rounded, strongly ventribiconvex shell. Its surface is delicately ornamented by faint striae, sometimes with small spines (see Fig. 4AB). The anterior commissure varies from nearly straight to gently unisulcate. The beak is short, erect, truncated by a large, oval to circular foramen of mesothyrid type; the beak ridges are distinct. The deltidial plates are disjunct and minute. The pedicle collar is wide and sessile. The teeth are short. $M$. eusticta has a complex brachial skeleton, consisting of a long loop with a full ring supported dorsally by the median septum (Fig. 4K); inner hinge plates well developed. Muscle scars are well visible on both valves.

The studied specimens are entirely consistent in external and internal morphologies with those hitherto described (Gaetani and Saccà, 1985a; Calzada, 1997), being, however, somewhat smaller than the specimens from Italy.

This species can be easily distinguished from common Megerlia truncata (Linnaeus, 1767) by its rounded shape, striate ornamentation, and different umbonal part (see Logan, 1979; Gaetani and Saccà, 1985a; Bitner, 1990).

The investigated specimens are very similar to the specimens from the Pliocene strata of Italy described as Megerlia echinata (Fisher and Oehlert, 1891) (Saccà, 1986). Saccà (1986) considers $M$. echinata as an intermediate form between $M$. truncata and $M$. eusticta.

\section{Occurrence}

The species Megerlia eusticta is restricted to the Pliocene, and it is known from Italy (Gaetani and Saccà, 1985a; Taddei Ruggiero, 1996) and Spain (Calzada, 1997).

\section{THE MEDITERRANEAN PLIOCENE BRACHIOPOD ASSEMBLAGES}

The Mediterranean Pliocene brachiopod assemblages are commonly composed of large terebratulids and various micromorphic brachiopods, but their composition at the species level can differ greatly. The species composition is clearly dependent on environmental conditions, and is not associated with the age. Lower and Upper Pliocene brachiopod assemblages are very similar or identical if they occur in the same sediments. The investigated assemblage from Velerín consists of Terebratula terebratula (=Terebratula calabra in Italian publications, see also discussion on $\mathrm{p}$.
181), Aphelesia bipartita, Megerlia eusticta, and very rare (only one specimen) Gryphus sp. Similar brachiopod assemblages composed of those three species or sometimes with rare additional elements, for instance Terebratulina retusa, Megathiris detruncata and/or Megerlia truncata, are known from Italy both from Lower and Upper Pliocene (Gaetani and Saccà, 1985a, b; Gaetani, 1986; Barrier et al., 1987; Taddei Ruggiero, 1996). The Terebratula/ Aphelesia/Megerlia assemblage is characteristic for the shallow water, typical circalittoral, sandy facies (Gaetani and Saccà, 1985a, b; Gaetani, 1986; Barrier et al., 1987) which is in agreement with conditions inferred for the Velerín outcrop. Aphelesia bipartita and Megerlia eusticta seem to be adapted to high-energy sandy bottoms (Gaetani and Saccà, 1985a; Gaetani, 1986; Barrier et al., 1987; Benigni and Robba, 1990). The increase in amount of muddy sediment alters the frequency of these two species. In the clayey units in northern Italy the assemblage is limited to the bioclastic interlayers and is almost dominated by Terebratula (Gaetani, 1986).

Taddei Ruggiero (1996) distinguished two circalittoral assemblages in the Upper Pliocene of the Murge area, southern Italy. One of them corresponds in composition to the assemblage discussed above, i.e. consists of Aphelesia bipartita, Terebratula calabra, and Megerlia eusticta. It is associated with finely detritic and muddy bottoms. The second assemblage recognized by Taddei Ruggiero (1996) is linked with hard substrate or coarsely detritic bottoms where Neocrania anomala, Megathiris detruncata, Argyrotheca cuneata, A. cordata, Megerlia truncata are common, while Megerlia eusticta and large Terebratula are very rare. The latter assemblage is very close to the brachiopod assemblage from the Almería region (SE Spain) described by Pajaud (1977).

In shallow-water littoral environment of the Empordà basin (NE Spain) Megathiris detruncata and Megerlia truncata dominate in the assemblage (90\% of all specimens), and Terebratula terebratula, Terebratulina retusa, and Argyrotheca cordata occur in negligible quantities (Encinas, 1992; Encinas and Martinell, 1992).

The Dallina/Fallax/Gryphus sphenoideus assemblage characteristic of the bathyal zone, described by Gaetani and Saccà (1984) and Gaetani (1986) from southern Italy, is not known from Spain.

\section{ACKNOWLEDGEMENTS}

The authors are grateful to R. Domènech (University of Barcelona) and M.C. Lozano and J.L. Vera (Museo Municipal de Estepona, Málaga) for their collaboration in the collecting of the material. D.E. Lee (University of Otago) kindly made comments on the genus Terebratula, and improved the language. MAB is very thankful to $G$. Aiello (Napoli) for help in translation of some Italian papers, and to S. Calzada (Barcelona) and A. Dulai (Budapest) for the opportunity to study the brachiopods kept in the Museu Geològic del Seminari and Hungarian Museum of Natural History, respectively. Comments by F. Álvarez (Oviedo) 
helped to improve the manuscript. Another anonymous reviewer is thanked for his highly critical review. Ms. G. Dziewińska (Warszawa) took the photographs. This research is part of the activities of the group SGR-93/348 of the Government of Catalonia and the project BT2000-0584 of the Science and Technology Ministry of Spain.

\section{REFERENCES}

Aguirre, J. 1995. Tafonomía y evolución sedimentaria del Plioceno marino en el litoral sur de España entre Cádiz y Almería. Unpublished PhD Thesis, University of Granada, Spain, 419 pp.

Anfossi, G., Brambilla, G. e Mosna, S. 1983. La fauna del Pliocene di Taino (Varese). Atii dell'Istituto Geologico della Università di Pavia, 30, 83-102.

Aranki, J.F. 1987. Marine Lower Pliocene Ostracoda of southern Spain with notes on the Recent fauna. Bulletin of the Geological Institutions, University of Uppsala, n.s. 13, 1-144.

Barrier, P., Casale, V., Costa, B., Di Geronimo, I., Olivieri, O. e Rosso, A. 1987. La sezione plio-pleistocenica di Pavigliana (Reggio Calabria). Bolletino della Società Paleontologica Italiana, 25, 107-144.

Benigni, C. and Robba, E. 1990. A Pliocene micromorph brachiopod-pectinid community. Atti del Quarto Simposio di Ecologia e paleoecologia delle Comunità Bentoniche, Sorrento, 1-5 Novembre 1988. Museo Regionale di Scienze Naturali - Torino, Nuova Serie, 604, 341-356.

Bitner, M.A. 1990. Middle Miocene (Badenian) brachiopods from the Roztocze Hills, south-eastern Poland. Acta Geologica Polonica, 40, 129-157.

Born, I. von 1778. Index rerum naturalium Musei Caesarei Vindobonensis. Pars 1. Testacea. Vindobonae, 458 pp.

Brébion, P., Demarcq, G., Lauriat, A. et Montenat, C. 1971. Le Pliocène de la région d'Elche (province d'Alicante, Espagne) et sa faune de mollusques. Estudios Geológicos, 27, 197-211.

Brébion, P., Lauriat-Rage, A., Pajaud, D., Pouyet, S. et Roman, J. 1978. Les faunes pliocènes des environs d'Aguiles (province d'Almeria et de Murcia, Espagne méridionale). Bulletin du Muséum National d'Histoire Naturelle, $3^{\mathrm{mmc}}$ série, 68, 55-76.

Brocchi, G. 1814. Conchiologia Fossile Subapennina. Vol. 2, Stamperia Reale, Milano, 712 pp.

Brunton, C.H.C. and Curry, G.B. 1979. British brachiopods. Synopses of the British Fauna (New Series), 17, 1-64.

Buckman, S.S. 1907. Brachiopod nomenclature: the genotype of Terebratula. Annals and Magazine of Natural History, Ser. 7, 19, 525-531.

Calzada, S. 1978. Braquiópodos tortonienses de Murcia. Estudios Geológicos, 34, 351-358.

Calzada, S. 1997. Miscelánea sobre braquiópodos. Batalleria, 7, 31-34.

Chamón, C., Estévez, C. y Piles, E. 1978. Mapa geológico de España, escala 1:50.000 MAGNA, Hoja $n^{0} 1072$ (Estepona). Servicio de Publicaciones del Ministerio de Industria y Energía, Madrid. 34 pp.
Cooper, G.A. 1959. Genera of Tertiary and Recent rhynchonellid brachiopods. Smithsonian Miscellaneous Collections, 139 (5), 1-90.

Cooper, G.A. 1981. Brachiopoda from the Gulf of Gascogne, France (Recent). Smithsonian Contributions to Paleobiology, 44, 1-35.

Cooper, G.A. 1983. The Terebratulacea (Brachiopoda), Triassic to Recent: a study of the brachidia (loops). Smithsonian Contributions to Paleobiology, 50, 1-445.

Dermitzakis, M. 1969. Geological researches of the Neogene deposits of the Hierapetra Province in Crete. Annales Géologiques des Pays Helléniques, 21, 342-484. [In Greek.]

Elliott, G.F. 1960. Brachiopodes tertiaires d'Arabie et de Syrie. Bulletin de la Société Géologique de France, $7^{\mathrm{e}}$ série, 2, 152-155.

Emig, C.C. 1989a. Distributional patterns along the Mediterranean continental margin (Upper Bathyal) using Gryphus vitreus (Brachiopoda) densities. Palaeogeography, Palaeoclimatology, Palaeoecology, 71, 253-256.

Emig, C.C. 1989b. Distribution bathymétrique et spaciale des populations de Gryphus vitreus (brachiopode) sur la marge continentale (Nord-Ouest Méditerranée). Oceanologica Acta, 12, 205-209.

Encinas, A. 1992. Paleobiología de los braquiópodos de la cuenca neógena del Empordà. Unpublished MSc thesis, Universitat de Barcelona, 180 pp.

Encinas, A. y Martinell, J. 1992. Braquiópodos del Plioceno del Empordà (Catalunya). III Congreso Geológico de España y VII Congreso Latinoamericano de Geología, Salamanca 1992, Actas tomo 1, 501-505.

Faura y Sans, M. 1916. Contribución a la fauna braquiopódica Astiense de Vilacolúm, Provincia de Gerona. Boletín de la Real Sociedad Española de Historia Natural, 16(6), 287-288.

Fischer, P. et Oehlert, D. P. 1891. Brachiopodes. Expéditions scientifiques du "Travailleur" et du "Talisman" pendant les années 1880, 1881, 1882, 1883. G. Masson, Paris, 140 pp.

Gaetani, M. 1986. Brachiopod palaeocommunities from the Plio/Pleistocene of Calabria and Sicily (Italy). In: Les Brachiopodes fossiles et actuels (Eds. P. R. Racheboeuf and C. C. Emig). Biostratigraphie du Paléozö̈que, 4, 477-483.

Gaetani, M. e Saccà, D. 1984. Brachiopodi batiali nel Pliocene e Pleistocene di Sicilia e Calabria. Rivista Italiana di Paleontologia e Stratigrafia, 90, 407-458.

Gaetani, M. e Saccà, D. 1985a. Brachiopodi neogenici e pleistocenici della provincia di Messina e della Calabria meridionale. Geologica Romana, 22 (1983), 1-43.

Gaetani, M. e Saccà, D. 1985b. Il genere Aphelesia (Rhynchonellida, Brachiopoda) nel Mio-Pliocene italiano. Rivista Italiana di Paleontologia e Stratigrafia, 91, 357-378.

Georgiades-Dikeoulia, E. 1984. Paleoenvironmental observations based on the Pliocene Marine Megafaunal Assemblages of Crete Island. In: Interim Colloquium on Mediterranean Neogene Marine Megafaunal Palaeoenvironments and Biostratigraphy (Eds. M.D. 
Dermitzakis et al.). Annales Géologiques des Pays Helléniques, 32, 79-85.

González Donoso, J.M. y Porta, J. de 1977. Datos preliminares sobre un afloramiento de materiales pliocénicos en Estepona (provincia de Málaga). Studia Geologica, 13, 31-57.

Guerra-Merchán, A., Palmqvist, P., Lozano-Francisco, M.C., Vera-Peláez, J.L. y Triviño-Rodríguez, A. 1996. Análisis sedimentológico y paleoecológico del yacimiento plioceno de Parque Antena (Estepona, Málaga). Revista Española de Paleontología, 11, 226234.

INTERNATIONAL COMMISSION ON ZOOLOGICAL NOMENCLATURE. 2000. Opinion 1959. Bulletin of Zoological Nomenclature (London), 57, 187-188.

King, W. 1850. A monograph of the Permian fossils of England. Palaeontographical Society Monograph, 3, 1258.

Lee, D.E. and Brunton, C.H.C. 1998. Terebratula Müller, 1776 (Brachiopoda): proposed designation of Anomia terebratula Linnaeus, 1758 as the type species. Bulletin of Zoological Nomenclature (London), 55, 220-223.

Lee, D.E. and Brunton, C.H.C. 2000. The brachiopod genus Terebratula: solutions to some historical, geological, and biological puzzles. The Millennium Brachiopod Congress, $10^{\text {th }}-14^{\text {th }}$ July 2000, London. Abstracts.

Linnaeus, C. 1758. Systema Naturae. L. Salrii, Stockholm, $823 \mathrm{pp}$

Linnaeus, C. 1767. Systema Naturae. Stockholm, pp. 5331327.

Llompart, C. y Calzada, S. 1982. Braquiópodos messinienses de la isla de Menorca. Boletín de la Real Sociedad Española de Historia Natural, 80, 185-206.

Logan, A. 1979. The Recent Brachiopoda of the Mediterranean Sea. Bulletin de l'Institut Océanographique Monaco, 72, 1-112.

Lozano-Francisco, M.C. 1997. Los Bivalvos del Plioceno de la provincia de Málaga. Unpublished $\mathrm{PhD}$ Thesis, University of Málåga, Spain. 734 pp.

Manceñido, M.O., Owen, E.F. and Morris, N.J. 1993. The dating of d'Orbigny's brachiopod and bivalve nominal taxa. Bulletin of Zoological Nomenclature (London), 50, 196-199.

Martinell, J. y Villalta, J.F. de 1977. Revisión y nuevas aportaciones a la fauna del yacimiento pliocénico de Vilacolum, Girona. Acta Geológica Hispánica, 12, $26-$ 28.

Megerle von Mühlfeld, J.K. 1811. Entwurf eines neuen Systems der Schaltiergehäuse. Gesellschaft Naturforschenden Freunde, Magazin, series 1, 1, 249-257.

Meznerics, I. 1943. Die Brachiopoden des ungarischen Tertiärs. Annales Historico-Naturales Musei Nationalis Hungarici, 36, 10-60.

Müller, O.F. 1776. Zoologiae Danicae prodromus seu animalium Daniae et Norvegiae indigenarum characteres, nomina, et synonyma imprimis popularium. Havniae, xxxii, 282 pp.

Muñiz-Solís, R. y Guerra-Merchán, A. 1994. Estudio malacológico del Plioceno de Estepona (Málaga). La familia Muricidae Rafinesque, 1815 (Gastropoda, Prosobranchia). Iberus, 12(1), 7-44.

Pajaud, D. 1976. Les Brachiopodes du Pliocène I de la Sierra de Santa Pola (sud d'Alicante, Espagne): Terebratula terebratula (Linné, 1758) et Phapsirhynchia sanctapaulensis nov. gen., nov. sp. Annales de la Société Géologique du Nord, 96, 99-106.

Pajaud, D. 1977. Les Brachiopodes du Pliocène I de la région d'Aguilas (sud d'Almeria, Espagne). Annales Paléontologie (Invertébrés), 63, 59-75.

Pedley, H.M. 1976. A palaeoecological study of the Upper Coralline Limestone, Terebratula-Aphelesia Bed (Miocene, Malta) based on bryozoan growth-form studies and brachiopod distributions. Palaeogeography, Palaeoclimatology, Palaeoecology, 20, 209-234.

Philippi, R.A. 1836. Enumeratio Molluscorum Siciliae. Vol. 1, 1-267, Berolini.

Philippi, R.A. 1844. Enumeratio Molluscorum Siciliae. Vol. 2, 1-293, Halis Saxonum.

Saccà, D. 1986. Megerlia echinata (Terebratulida, Brachiopoda) nel Pliocene della Sicilia e della Calabria meridionale. Rivista Italiana di Paleontologia e Stratigrafia, 92, 281-292.

Sacco, F. 1902. I Brachiopodi dei terreni terziarii del Piemonte e della Liguria. Carlo Clausen, Torino, 50 pp.

Sanz de Galdeano, C., Serrano, F., López Garrido, A.C. and Martín Pérez, J.A. 1993. Palaeogeography of the Late Aquitanian-Early Burdigalian Basin in the Western Betic Internal Zone. Geobios, 26, 43-55.

Seguenza, G. 1871. Studii paleontologici sui brachiopodi terziarii dell'Italia Meridionale. Bullettino della Società Malacologica Italiana, 4, 1-74.

Spano, C. 1989. Macrofauna circalitorale del Pliocene inferiore di Capo S. Marco (Sardegna occidentale). Rivista Italiana di Paleontologia e Stratigrafia, 95, 137 172.

Taddei Ruggiero, E. 1994. Neogene Salento brachiopod palaeocommunities. Bollettino della Società Paleontologica Italiana, 33, 197-213.

Taddei Ruggiero, E. 1996. Biostratigrafia e paleoecologia delle Calcarenti di Gravina nei dintorni di cerignola (brachiopodi e foraminiferi). Memorie della Società Geologica Italiana, 51, 197-207.

Tavani, G. 1969. Brachiopodi, Anellidi e Molluschi del Pliocene di Punta Ristola (Capo di Leuca - Puglia). Atti della Società Toscana di Scienze Naturali, 74, 23- 41.

Vera-Peláez, J.L. 1996. Turridae (Mollusca, Gastropoda) del Plioceno malacitano. Unpublished PhD Thesis, University of Málaga, Spain. 864 pp. 